\author{
NAMA : RISWANDA IMAWAN EKA PUTRA \\ NPM $\quad: \mathbf{1 7 1 1 0 5 0 0 0 1}$ \\ FAKULTAS : ILMU KOMPUTER \\ JURUSAN : SISTEM INFORMASI \\ EMAIL ： riswanda.1711050001@mail.darmajaya.ac.id
}

\title{
ANALYST PROSES BISNIS
}

\section{Pengertian Tugas \& Tanggung Jawab Business Analyst}

Menurut wikipedia seorang Business Analyst adalah seseorang yang menganalisis sebuah organisasi, perusahaan maupun instansi secara (nyata atau hipotetis) dan mendesain proses dan sistem, menilai model bisnis menintegrasikannya dengan teknologi. Nah Tugas seorang business Analyst adalah memahami struktur, kebijakan, dan operasi dari suatu organisasi, dan untuk merekomendasikan solusi yang memungkinkan organisasi untuk mencapai tujuannya. Jadi Analis Bisnis diminta untuk menganalisis, mengubah dan akhirnya menyelesaikan masalah bisnis dengan bantuan teknologi baik dalam penggunaan alat teknologi terbaru, aplikasi maupun teknologi lainnya.

\section{Bidang analisis bisnis}

Nah dilihat dari bidangnya bisnis analis bisa dibedakan menurut tingkatan bidang antara lain sebagai berikut.

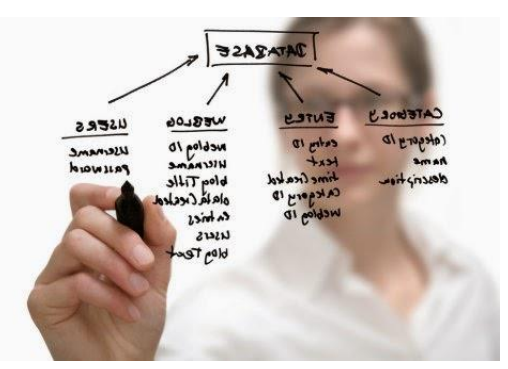

- Perencanaan strategis adalah bisnis analis untuk mengidentifikasi kebutuhan bisnis organisasi

- Analisis model bisnis adalah bisnis analis yang bekerja sesuai bidang untuk menentukan kebijakan organisasi dan pendekatan pasar

- Proses desain adalah bisnis analis yang bekerja sesuai bidang kerjanya untuk membakukan alur kerja organisasi

- Analisis sistem adalah bisnis analis yang bekerja untuk menginterpretasikan aturan bisnis dan persyaratan untuk sistem teknis (umumnya dalam IT)

Business Analyst adalah seseorang yang merupakan bagian dari operasi bisnis dan bekerja dan berkaitan dengan Teknologi Informasi untuk meningkatkan kualitas layanan yang disampaikan, kadang-kadang membantu dalam Integrasi dan Pengujian solusi baru di perusahaan, instansi maupun organisasi. Business analyst juga dapat mendukung pengembangan materi pelatihan, berpartisipasi dalam pelaksanaannya, dan memberikan dukungan pasca implementasi. Hal ini mungkin melibatkan pengembangan rencana proyek dan seringkali memerlukan keterampilan manajemen proyek. 


\section{Tanggung Jawab \& Syarat Seorang Business Analyst}

Pada umumnya Business Analyst memiliki latar belakang teknik, memiliki pengalaman kerja sebagai programmer atau insinyur, atau menyelesaikan gelar Ilmu Komputer. Bisnis analis tidak harus selalu bekerja dalam proyek-proyek yang berkaitan dengan IT, keahliannya juga sering diperlukan dalam bidang pemasaran dan keuangan juga. Biasanya beberapa perusahaan atau industri yang membutuhkan jasa dari bisnis analis biasanya yang bergerak di bidang keuangan, perbankan, asuransi, telekomunikasi, utilitas, layanan perangkat lunak dan sebagainya. Business analyst memiliki tanggung jawab memahami struktur, kebijakan, dan proses produksi suatu perusahaan maupun organisasi dan merekomendasikan solusi, cara, metode yang memungkinkan organisasi untuk mencapai tujuannya dan memiliki jiwa problem solver.

\section{Analist Proses}

Kompleksitas Dinamis adalah kompleksitas karena banyaknya kemungkinan kejadian yang bisa terjadi seiring berjalannya waktu. Sifat dinamis memang memiliki hubungan erat dengan dimensi waktu. Bermain catur adalah contoh kompleksitas dinamis ini, karena banyaknya kemungkinan yang bisa terjadi dalam mengambil keputusan, dan ketika keputusan telah dilakukan (menggerakkan biji catur) terbukalah kemungkinan-kemungkinan baru yang harus dipertimbangkan.

Sebuah sistem akan memiliki sifat dinamis ketika ada unsur manusia didalamnya, karena setiap manusia adalah makhluk yang memiliki satu unsur unik: ketidakpastiannya dalam mengambil keputusan. Ditambah pula dengan kenyataan kalaupun mengambil keputusan sering tidak seperti yang diduga. itu jika satu orang manusia, bagaimana dengan organisasi yang lebih dari satu manusia yang saling berinteraksi. Sistem dengan unsur manusia sering disebut sebagai HAS - Human Activity Systems - Sistem Aktivitas Manusia, dan pasti memiliki kompleksitas dinamis.

Kompleksitas Statis adalah kebalikan dari Dinamis, dimana hanya ada satu kemungkinan kejadian yang bisa terjadi saat sedang melakukan analist proses. 


\section{REFERENCE (Based ISO 690)}

[1] A. S. Putra And O. M. Febriani, "Knowledge Management Online Application In Pdam Lampung Province," In Prosiding International Conference On Information Technology And Business (Icitb), 2018, Pp. 181-187.

[2] A. S. Putra, O. M. Febriani, And B. Bachry, "Implementasi Genetic Fuzzy System Untuk Mengidentifikasi Hasil Curian Kendaraan Bermotor Di Polda Lampung," J. Sist. Inf. Dan Manaj. Basis Data, Vol. 1, No. 1, Pp. 21-30, 2018.

[3] O. M. Febriani And A. S. Putra, "Sistem Informasi Monitoring Inventori Barang Pada Balai Riset Standardisasi Industri Bandar Lampung,” J. Inform., Vol. 13, No. 1, Pp. 90-98, 2014.

[4] Putra, Arie Setya. "2018 Artikel Struktur Data, Audit Dan Jaringan Komputer." (2018).

[5] Putra, A. S. (2018, July 17). Paperplain Fundamental Create Application With Borland Delphi 7.0 University Of Mitra Indonesia. Retrieved From Osf.Io/Pbrn

\section{REFERENCE (Based APA)}

Putra, A. S., Aryanti, D. R., \& Hartati, I. (2018, November). Metode SAW (Simple Additive Weighting) sebagai Sistem Pendukung Keputusan Guru Berprestasi (Studi Kasus: SMK Global Surya). In Prosiding Seminar Nasional Darmajaya (Vol. 1, No. 1, pp. 85-97).

Sari, D. P., Febriani, O. M., \& Putra, A. S. (2018, November). Perancangan Sistem Informasi SDM Berprestasi pada SD Global Surya. In Prosiding Seminar Nasional Darmajaya (Vol. 1, No. 1, pp. 289-294).

Putra, A. S. (2018). Paperplain: Execution Fundamental Create Application With Borland Delphi 7.0 University Of Mitra Indonesia.

Putra, A. S., Sukri, H., \& Zuhri, K. Sistem Monitoring Realtime Jaringan Irigasi Desa (JIDES) Dengan Konsep Jaringan Sensor Nirkabel. IJEIS (Indonesian Journal of Electronics and Instrumentation Systems), 8(2), 221-232.

Darmawan, A., Yuliawati, D., Marcella, O., \& Firmandala, R. (2016). Sistem Absensi dan Pelaporan Berbasis Fingerprint dan SMS Gateway. EXPLORE, 7(1). 
Febriani, O. M., Wahyuni, T., \& Yusuf, S. (2017). DESIGN OF WEBSITE-BASED

INFORMATION SYSTEM FOR EDOCUMENT ADMINISTRASI IN THE COMMUNITY

SERVICE UNIT (A Case Study at Rajabasa District). INTERNATIONAL JOURNAL OF

COMPUTERS \& TECHNOLOGY, 16(7), 7010-7020.

Febriani, O. M., \& Wahyuni, T. (2017, October). PERANCANGAN SISTEM E-DOCUMENT ADMINISTRASI LOGBOOK PENELITIAN PADA UNIT LAYANAN DI BANDAR LAMPUNG. In Prosiding Seminar Nasional Darmajaya (Vol. 1, No. 1, pp. 187-194).

Febriani, O. M., \& Permadi, A. B. (2017). Implementasi Sistem Aplikasi Data Bimbingan dan Pelanggaran Siswa pada Sekolah Menengah Atas di Lampung Tengah dengan Metode Analisis dan Desain Sistem Terdistribusi (SSAD). EXPERT, 7(1).

Febriani, O. M., \& Ambarwati, L. (2015). PERANCANGAN APLIKASI PENGOLAHAN DATA PENJUALAN UKM KELANTING KHAS TELO DESA SIDOHARJO KECAMATAN JATI AGUNG KABUPATEN LAMPUNG SELATAN. Jurnal Teknologi Informasi dan Bisnis Pengabdian Masyarakat Darmajaya, 1(1), 77-95.

Febriani, O. M. (2015). Rancang Bangun Aplikasi E-commercemenggunakan Freewebstore pada UKM Kelanting di Desa Sidoharjo Lampung Selatan. Prosiding Sembistek 2014, 1(02), 446-458. 